\title{
Microstructure and Microanalysis of Porous Glass Obtained by Sintering of Vitreous Powders from Cr-Ni Sludge
}

\author{
S. Ballesteros Elizondo * and Jesús Ma. Rincón ** \\ * Laboratory of Process Equipment, CIATEQ, AC, Advanced Technology Centre, Unit Bernardo \\ Quintana, Av Manantiales No. 23-A, Parque Industrial Bernardo Quintana, CP 26246, El Marqués \\ Querétaro, México sballes@ciateq.mx \\ ** The Lab/ Group of Glassy and Ceramic Materials, Instituto E. Torroja of Construction Sciences \\ CSIC, c/ Serrano Galvache 4, 28033, Madrid Spain.jrincon@ietcc.csic.es
}

The sintering of vitreous powders (frits), which were obtained from industrial waste, was studied in the thermal treatment process in order to manufacture traditional based silicate glasses and glass ceramics after the vitrification process. The sintering process facilitates the moulding and expands the possibilities for manufacturing glass ceramics. The process includes physical and chemical (liquid phase formation, dissolution and crystallization) and shape changes (shrinkage and deformation) ${ }^{[1-2]}$. In the cooling step, the more dense material works as phase solder for the dust grains within the internal make-up of the material. The final microstructure is influenced by the grains size and shape which is also affected by the density and porosity distribution of the final product. Crystal growth occurs in the dense polycrystalline bridges of the porous glass ceramic material ${ }^{[3]}$.

For years sintering has been focused towards the use of clayed natural raw materials or pure oxides for the production of structural and/or advanced ceramics. This is a proposal to use alternative raw materials that are based on inorganic industrial wastes which is of increasing interest for recycling wastes and environmental policies and gives rise to materials which can be used in construction building ${ }^{[4]}$. Over time, the use of microscopy and microanalysis for microstructure characterization on glassy materials has given many scientific and technical benefits ${ }^{[5]}$. The research shown here is summarized with the HSM (hot stage microscopy) and the SEM/ EDS (scanning electron microscopy and $\mathrm{X}$ - rays energy dispersive microanalysis) that show vitreous grains starting to sinter as well as the final microstructure from the composition of original glass presented in the Table 1.

The raw material used to obtain the glass powders was a hazardous sludge containing $\mathrm{Cr}$ and $\mathrm{Ni}$. After vitrification of such waste, the inert vitreous powders have been compacted and sintered at high temperature in the range of $700-1000^{\circ} \mathrm{C}$ by performing a thermal cycle of one and two stages. The final product is a glass ceramic containing random and interconnected porosity which could be used in the construction industry in Mexico due to its mechanical and chemical stability. Figure 1 shows the heating and sintering process documented in a HSM (Misura equipment). The sample was a manually compacted glass powder in a cylindrical cell of $2 \mathrm{~mm}$ diameter $\mathrm{x} 3 \mathrm{~mm}$ height at a heating rate of $10^{\circ} \mathrm{C} / \mathrm{min}$.

Figure 2 shows the SEM micrographs (SEM model Philips XL30 with computer and EDS TMPDX4i energy dispersive spectrometer) depicting the initial melting at the edges during the first stage of sintering and crystallization in the temperature range $700-1100{ }^{\circ} \mathrm{C}$.

Lastly, figure 3 shows the microstructure of the final porous and compacted material that depicts grains of irregular size and shape after the combined cycle of $700^{\circ} \mathrm{C}$ for $10 \mathrm{~min}$ followed by heating of $10^{\circ} \mathrm{C} / \mathrm{min}$ until $1000^{\circ} \mathrm{C}$ and then stabilized for $10 \mathrm{~min}$. In this second stage of sintering the grains coalesce but due to their tendency to devitrify, a high volume fraction of small crystals embedded in a residual glass matrix is produced. The SEM micrographs at different magnifications $(1000,1500$ and 2500x) and $15 \mathrm{kV}$ show the presence of porous material with spheroidal ferrite /spinel crystals and augite- pyroxene crystals whose composition was confirmed by EDS microanalysis being similar to glass ceramics researched in previous work ${ }^{[6-7]}$. 
Table 1. Average composition of original glass sintered for obtaining porous glass ceramic

\begin{tabular}{|c|c|c|c|c|c|c|c|c|}
\hline \multicolumn{3}{|c|}{ wt $\%$ oxides } & $\mathrm{SiO}_{2}$ & $\mathbf{A l}_{2} \mathbf{O}_{3}$ & $\mathrm{CaO}$ & $\mathrm{Fe}_{2} \mathrm{O}_{3}$ & $\mathbf{F e}$ & $\mathrm{Na}_{2} \mathrm{O}$ \\
\hline \multicolumn{3}{|c|}{ Major components } & 64.0 & 6.47 & 8.10 & 9.91 & 3.62 & 4.91 \\
\hline & $\mathrm{Cr}_{2} \mathrm{O}_{3}$ & $\mathrm{MnO}$ & $\mathbf{K}_{2} \mathbf{O}$ & $\mathrm{TiO}_{2}$ & MgO & $\mathrm{NiO}$ & $\mathrm{ZrO}_{2}$ & $\mathbf{F e O}$ \\
\hline $\begin{array}{l}\text { Minor } \\
\text { components }\end{array}$ & 0.61 & 0.51 & 0.43 & 0.35 & 0.24 & 0.24 & 0.14 & 0.064 \\
\hline & & & & & & $\mathbf{C}$ & $\mathbf{S}$ & $\mathbf{P}_{2} \mathbf{O}_{5}$ \\
\hline \multicolumn{6}{|c|}{ Volatile oxides and elements } & 0.21 & 0.11 & 0.04 \\
\hline
\end{tabular}
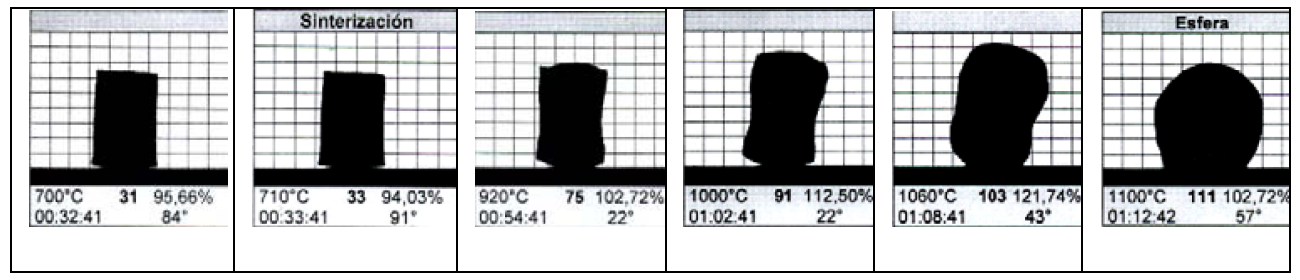

Figure1. HSM images with evolution of glass compact with heating
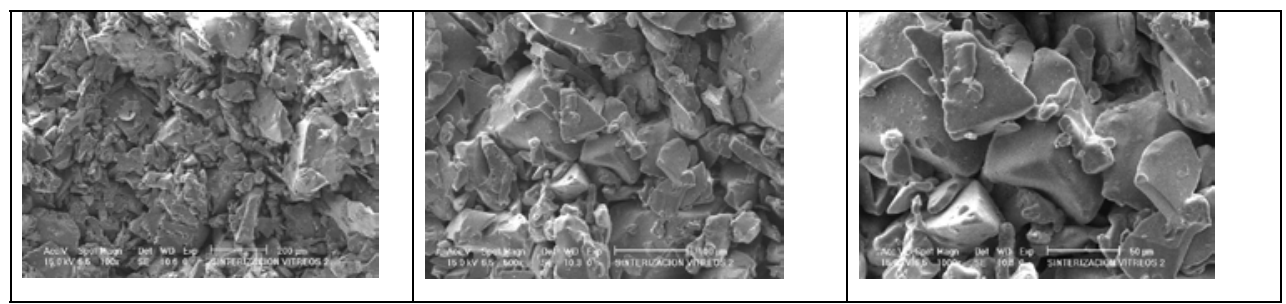

Figure 2. SEM micrographs of irregular glassy grains at different magnifications (100, $500 \mathrm{y} 1000 \mathrm{x}$, respectively) showing the incipient meeting in the grain edges.

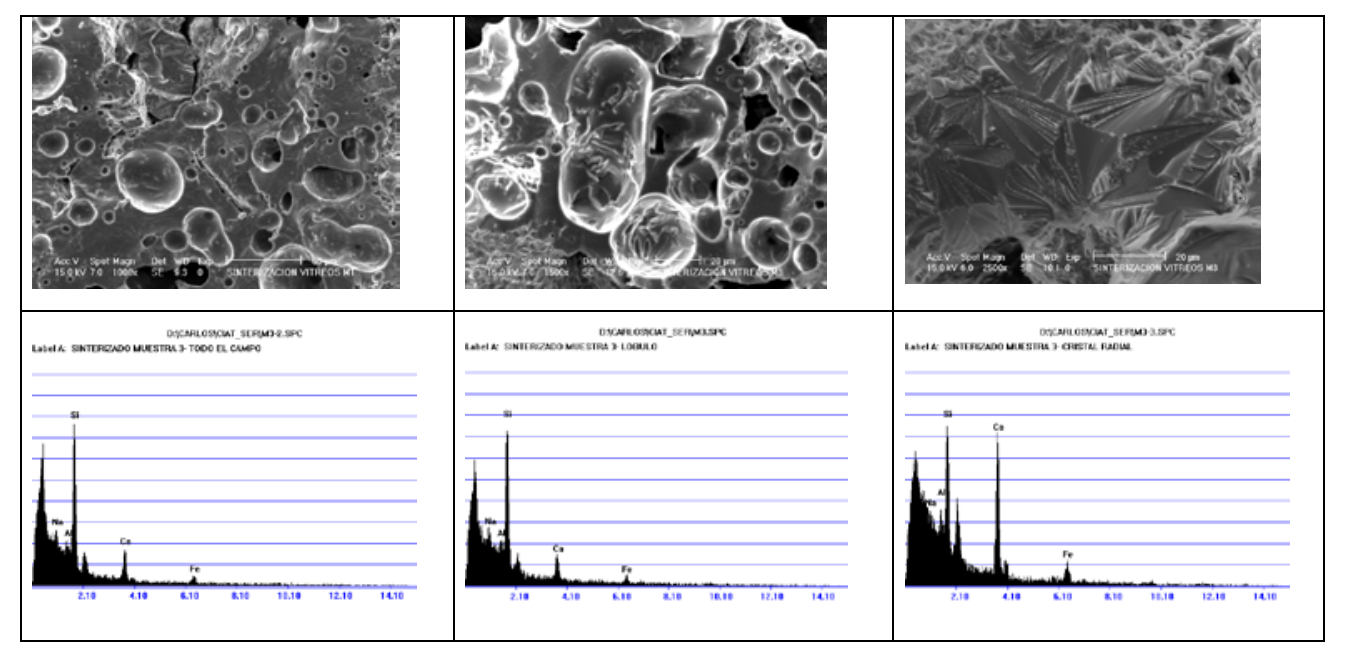

Figure 3. SEM/ EDS microanalysis of porous glass ceramic obtained under combined cycle of $700^{\circ} \mathrm{C} 10 \mathrm{~min}$ $+1000^{\circ} \mathrm{C} / 10 \mathrm{~min}(1000,1500$ and $2500 \mathrm{x}$, respectively)

\section{References:}

[1] S. Jr Schneider. "Engineered Mats. Handbook Vol 4, Ceramics and Glasses, ASM Intern. Committee, February (2000), p.264.

[2] J. Martin- Márquez, J. Ma. Rincón and M. Romero, Effect of firing temperature on sintering of porcelain stoneware tiles, Ceramics International 34 (2008) 1867-1873

[3] A. R. Boccaccini, M. Bücker, P. A. Trusty and J. Ma. Rincón, Sintering behaviour of compacts made from Television Tube (TV) Glasses, Glass Technology 38 (1997) 128-133

[4 ] M. Romero y J. Ma. Rincón, Glass-ceramics as building materials, Materiales de Construcción 46 (1996) 242- 243.

[5] J.Ma. Rincón and M. Romero, Microstructural Characterization by Electron Microscopy of Ceramics and Glasses, Microscopy and Analysis, nov. (1996) 23-25.

[6] Surface and Bulk Crystallization of Glass- Ceramic in the $\mathrm{Na}_{2} \mathrm{O}-\mathrm{CaO}-\mathrm{ZnO}-\mathrm{PbO}-\mathrm{Fe}_{2} \mathrm{O}_{3}-\mathrm{Al}_{2} \mathrm{O}_{3}-\mathrm{SiO}_{2}$ System Derived from a Goethite Waste, J. Amer. Ceram. Soc. 82 (1999)5, 1313- 1318

[7] J. Ma. Rincón, J. Caceres, C. J. R. Gonzalez- Oliver, D. O. Russo, A. Petkova and H. Hristov, Thermal and sintering 